\section{Greenfield and Brownfield Investments and Economic Growth: Evidence from Central and Eastern European Union Countries}

\author{
Yilmaz Bayar \\ Usak University, Faculty of Economics and Administrative Sciences, Turkey \\ yilmaz.bayar@usak.edu.tr
}

\begin{abstract}
Global foreign direct investment flows in terms of greenfield and brownfield investments have increased during the recent three decades resulting from the accelerating globalization. The considerable increases in the flows of foreign direct investment have many eventualities for the national economies. This study investigates the mutual effects among greenfield and brownfield (mergers and acquisitions) investments and economic growth in Central and Eastern European Union countries during the 2003-2015 period employing panel data analysis. The findings revealed that both greenfield and brownfield investments had positive influence on the economic growth, but the influence of greenfield investments was found to be relatively higher. Furthermore, one-way causality was discovered from both greenfield and brownfield investments to the economic growth.
\end{abstract}

Keywords: Greenfield investments, brownfield investments, economic growth, panel data analysis, Central and Eastern European Union countries

\section{Introduction}

Cross-border capital flows have risen substantially in terms of both foreign direct investment (FDI) and portfolio investments during the last 40 years. In this context, global FDI inflows rose to US \$2,135.7029 billion in 2015 from US \$10.1724 billion in 1970 (World Bank, 2017). FDIs can be implemented in two ways: as a greenfield investment or brownfield investment (transnational mergers and acquisitions [M\&A]). Brownfield investments consist of merging with or buying an existing facility; greenfield investments include constructing a new non-existent facility in a country.

FDI inflows can influence the economic growth positively by way of making contributions to the capital accumulation within the context of neoclassical growth theory or through knowledge and technological spillovers within the scope of endogenous growth theory (Solow, 1957; De Mello, 1999). Moreover, FDI inflows can affect the economic growth indirectly by means of enhancing the financial development. Nonetheless, the FDI-growth nexus can differ depending on the type of FDI inflows. Theoretically greenfield investments can contribute to the capital accumulation and productivity with forming the new facilities. But brownfield investments, including M\&As, may not raise capital accumulation and/or productivity in the host country. Nevertheless, brownfield investments also
ORIGINAL SCIENTIFIC PAPER

RECEIVED: JULY 2017

REVISED: AUGUST 2017

ACCEPTED: AUGUST 2017

DOI: 10.1515/ngoe-2017-0015

UDK: $339.7: 330.34$

JEL: F21, F23, F43, O40, C33

Citation: Bayar, Y. (2017). Greenfield and Brownfield Investments and Economic Growth: Evidence from Central and Eastern European Union Countries. Naše Gospodarstvo/Our Economy, 63(3), 19-26. DOI: 10.1515/ngoe-2017-0015

\section{NG OE}

NAŠE GOSPODARSTVO OUR ECONOMY

\section{vol.63 No.3 2017}

pp. $19-26$ 
can influence the economic growth positively by means of new knowledge and technology transfer. Consequently, the net impact of both greenfield and brownfield investments on economic growth is unclear considering the theoretical considerations. Furthermore, empirical literature summary in Section 2 also supports this assertion.

In this research paper, the interplay among greenfield and brownfield investments and economic growth will be investigated for the sample of Central and Eastern European Union (CEEU) countries (Bulgaria, Croatia, Czech Republic, Estonia, Hungary, Latvia, Lithuania, Poland, Romania, Slovakia, and Slovenia), which have attracted significant amount of greenfield and brownfield investments resulting from institutionally and economically transformation with the contribution of European Union membership. The shortand-long run interaction among greenfield and brownfield investments and economic growth will be analyzed with panel cointegration test of Basher and Westerlund (2009) and panel causality test of Dumitrescu and Hurlin (2012). The extensive researches have been implemented to analyze the influence of FDI inflows on the economic growth in the CEEU countries. But the present paper will make a contribution to the relevant literature by researching the interplay between brownfield investments, greenfield investments, and economic growth for CEEU countries. In other words, the paper investigates the impact of two main types of FDIs on economic growth in CEEU countries. In this context, the relevant empirical literature will be taken place in the coming section, then data and method will be summarized in Section 3. Section 4 includes empirical analysis and the major findings. Finally, the paper comes to the conclusion in Section 5.

\section{Literature Review}

The considerable increases in the global FDI flows have directed scholars to investigate the economic impacts of FDI flows. In this context, some scholars have focused on the FDI-growth nexus and discovered that FDI inflows made a positive contribution to the economic growth (e.g., see Borensztein et al., 1998; Li \& Liu, 2005; Pegkas, 2015; Iamsiraroj \& Ulubaşoğlu, 2015; Iamsiraroj, 2016). However, few scholars have investigated the interaction among greenfield and brownfield investments and economic growth and revealed different findings (e.g., see Calderon et al., 2004; Wang \& Wong, 2009; Neto et al., 2010; Harms \& Meon, 2014; Eren \& Zhuang, 2015; Zvezdanović-Lobanova et al., 2016).

In one of the early studies, Moon et al. (2003) researched the impacts of brownfield FDI in South Korea, China, and Hong Kong during the 1999-2002 period with case studies employing a diamond model and revealed that brownfield investments positively affected the economic growth. On the other side, Calderón et al. (2004) analyzed the interaction among greenfield FDI inflows, brownfield investments, and economic growth in 72 countries (50 developing and 22 developed countries) during the 19782001 period employing vector autoregression analysis and revealed that economic growth affected the both types of FDI inflows positively, impact of economic growth on the greenfield and brownfield FDI inflows were found to be larger in the developed countries, while both greenfield and brownfield investments had no significant impact on the economic growth.

In another study, Wang and Wong (2009) researched the influence of greenfield and brownfield FDIs on the economic growth in 84 countries during the 1987-2001 period employing panel regression and discovered that greenfield FDIs positively affected the economic growth, while brownfield FDIs negatively influenced economic growth. Neto et al. (2010) researched the same question for a sample of 53 countries during the 1996-2006 period using causality test and regression analysis and revealed that greenfield FDI inflows positively affected economic growth, but brownfield investments did not make a significant contribution to economic growth.

Zhuang and Griffith (2013) also analyzed the impact of greenfield and brownfield FDI inflows on the inequality in 93 countries during the 1990-2009 period employing panel regression and found that greenfield FDI inflows positively affected the income inequality, while brownfield FDI inflows had no significant effects on the income inequality. On the other hand, Ashraf et al. (2015) explored the influence of greenfield and brownfield FDIs on the productivity in 123 developed and developing states during the 20032011 period employing panel regression and revealed that brownfield FDIs positively affected total factor productivity, while greenfield FDI inflows made no significant contributions to the productivity. Furthermore, both greenfield and brownfield investments had no significant effects on the productivity in developing countries, while brownfield FDIs positively affected total factor productivity.

On the other hand, Harms and Meon (2014) analyzed the influence of greenfield and brownfield FDIs on the economic growth in 78 countries from emerging and developing economies over the period of 1987-2005 employing panel regression and revealed that greenfield FDIs positively influenced the economic growth, while brownfield FDIs made no significant contributions to economic growth. Eren and Zhuang (2015) researched the influence of greenfield and brownfield FDIs on economic growth in 12 EU members 
(10 Central and Eastern European states, Cyprus and Malta) over the period of 1999-2010 employing panel regression and discovered that both greenfield and brownfield FDIs did not make a significant contribution to the economic growth on their own, their impacts depend on the absorptive capacities of the countries. Furthermore, a certain minimum human capital level is essential for the positive interplay among greenfield FDIs and economic growth, while a developed financial sector is necessary for the positive interaction between brownfield FDIs and economic growth.

In another study, Zvezdanović-Lobanova et al. (2016) researched the impact of brownfield FDIs on economic growth in 22 European transition economies over the period of 2000-2014 using panel regression and discovered that brownfield FDIs had a negative effect on economic growth in the current period, but the lagged values of brownfield FDIs positively influenced economic growth. Finally, Luu (2016) researched the influence of greenfield and brownfield FDIs on economic growth in emerging economies during the 2003-2014 period employing dynamic panel regression and discovered that both types of FDI inflows positively affected the economic growth.

\section{Data and Econometric Methodology}

In this paper, the long- and short-run interaction among greenfield investments, brownfield investments, and economic growth in the CEEU countries during the 20032015 period was analyzed with panel data analysis.

\section{Data}

In our study, economic growth was represented by growth rate of real GDP per capita and extracted from the database of World Bank (2016), as seen in Table 1. On the other hand, greenfield FDI inflows and brownfield FDI inflows were extracted from the database of UNCTAD (United Nations Conference on Trade and Development) (2016) and used as a percent of GDP in the model.
The study period was selected as 2003 and 2015 by considering the existence of data and the sample of the study consisted of 11 CEEU countries including Bulgaria, Croatia, Czech Republic, Estonia, Hungary, Latvia, Lithuania, Poland, Romania, Slovakia, and Slovenia. Finally, empirical analysis was implemented with the software packages of Eviews 9.0, Stata 14.0, and Gauss 11.0.

\section{Econometric methodology}

In the empirical analysis, first cross-section dependence among the cross-section units of the panel was investigated by $C D_{L M 1}$ test of Breusch and Pagan (1980) and $L M_{a d j}$ test of Pesaran et al. (2008), while homogeneity of the cointegrating coefficients was examined with the adjusted delta test of Pesaran and Yamagata (2008). Then integration levels of the series were analyzed by PANKPSS (Panel Kwiatkowski, Phillips, Schmidt and Shin) test of Carrion-i-Silvestre et al. (2005), taking notice of the cross-sectional dependence and structural breaks in the study period and the existence of cross-sectional dependence and heterogeneity among the variables. The causal interplay among greenfield and brownfield FDIs and economic growth was examined by means of error correction model. The long-run interaction between the series was analyzed with cointegration test of Basher and Westerlund (2009). Furthermore, the slope coefficients were estimated with panel an augmented mean group (AMG) of Eberhardt and Bond (2009). Finally, causal interaction among the series was analyzed with causality test of Dumitrescu and Hurlin (2012).

\section{Empirical Analysis}

In our study, the long- and short-run interaction among greenfield investments, brownfield investments, and economic growth in CEEU countries during the 2003-2015 period was analyzed with panel cointegration test of Basher and Westerlund (2009) and panel causality test of Dumitrescu and Hurlin (2012).

Table 1. Data Description

\begin{tabular}{lcc} 
Variables & Symbols & \\
\hline Real GDP per capita growth (annual, \%) & GRW & World Bank (2016) \\
\hline Greenfield FDI inflows (annual, \% of GDP) & GFDI & UNCTAD (2016) \\
\hline Brownfield FDI inflows (annual, \% of GDP) & BFDI & UNCTAD (2016) \\
\hline
\end{tabular}

Source: Authors’ own elaboration 


\section{Cross-sectional dependency and homogeneity tests}

The presence of cross-sectional dependence among greenfield and brownfield investments and economic growth was researched with $C D_{L M 1}$ test of Breusch and Pagan (1980) and $L M_{\text {adj }}$ test of Pesaran et al. (2008) because time dimension of the variables $(T=13)$ is higher than the number of cross-section units $(N=11)$. The $L M_{a d j}$ test of Pesaran et al. (2008) was also employed because the $C D_{L M 1}$ test may yield biased results while ensemble average equals to zero, but individual average does not equal to zero. In this case, the bias was eliminated with adding the mean and variance to the test statistic. The results of both tests about cross-sectional dependence are displayed in Table 2.

The null hypothesis was rejected because the $p$-value was found to be lower than $5 \%$, and we concluded that there was cross-sectional dependence among the series. Furthermore, the homogeneity of slope coefficients was analyzed with an adjusted delta tilde test of Pesaran and Yamagata (2008) (the test results are displayed in Table 2). We declined the null hypothesis; the cointegrating coefficients are homogeneous because $p$-value was found to be lower than $5 \%$. Thus, the cointegrating coefficients were found to be heterogeneous.

\section{PANKPSS unit root test}

The cross-section dependence and heterogeneity of the cointegrating coefficients were discovered in consequence of the test results in Table 2. The presence of the international financial crisis and Eurozone sovereign debt crisis in the study period and cross-sectional dependence dictates us to select a unit root test considering structural breaks and cross-sectional dependence. Therefore, the integration levels of the series were analyzed with the PANKPSS test of Carrion-i-Silvestre et al. (2005), thus enabling the structural breaks in constant and trend (the test results of first-differenced variables are displayed in Table 3). We revealed that all the variables were I(1). Furthermore, the test revealed structural breaks in 2008, 2009, 2010, 2011, and 2012 corresponding to the global financial crisis and Eurozone sovereign debt crisis for the cross-section units.

\section{Basher and Westerlund (2009) cointegration test}

The cointegration test of Basher and Westerlund (2009) can examine the cointegrating relationship for nonstationary series at the level, taking into account cross-sectional dependence and structural breaks. But the test can allow for maximum three breaks. The cointegration test of Basher and Westerlund (2009) was conducted, and the major findings are displayed in Table 4. The null hypothesis (there is cointegrating relationship among the series) was accepted when the test version considered the structural breaks were applied, and we discovered a cointegrating relationship among greenfield and brownfield investments and economic growth. However, the test version, via disregarding the structural breaks, indicated no cointegrating relationship among the series.

The slope coefficients were estimated with the panel AMG method of Eberhardt and Bond (2009), which regards cross-sectional dependence and heterogeneity (the findings are displayed in Table 5).

The problems of heteroscedasticity and autocorrelation were dissipated by the Newey-West method. The results showed that both greenfield FDI inflows and brownfield FDIs positively affected the economic growth. After all, the positive influence of greenfield investments on economic growth was found to be relatively higher when compared with brownfield investments.

Table 2. Results of Cross-Section Dependence and Homogeneity Tests

\begin{tabular}{|c|c|c|c|c|}
\hline Variables & $C D_{L M 1}$ test statistic & $C D_{L M 1} p$-value & $L M_{\text {adj }}$ test statistic & $L M_{\text {adj }} p$-value \\
\hline GRW & 9.372 & 0.002 & 19.453 & 0.001 \\
\hline GFDI & 8.026 & 0.003 & 12.044 & 0.015 \\
\hline BFDI & 9.561 & 0.000 & 16.722 & 0.002 \\
\hline \multicolumn{5}{|c|}{ Homogeneity tests of cointegrating coefficients } \\
\hline Test & Test stati & \multicolumn{3}{|c|}{$p$-value } \\
\hline$\Delta$ & 23.56 & \multicolumn{3}{|c|}{0.002} \\
\hline$\Delta_{\text {adj }}$ & 18.03 & \multicolumn{3}{|c|}{0.014} \\
\hline
\end{tabular}

Source: Authors' own elaboration based on the results of cross-sectional dependence and homogeneity tests 
Table 3. Results of PANKPSS Unit Root Test

\begin{tabular}{lcccccc}
\hline \multirow{2}{*}{ Country } & \multicolumn{2}{c}{ DGRW } & \multicolumn{2}{c}{ DGFDI } & \multicolumn{2}{c}{ DBFDI } \\
\cline { 2 - 7 } & Test Statistic & Structural Breaks & Test Statistic & Structural Breaks & Test Statistic & Structural Breaks \\
\hline Bulgaria & $0.097^{*}$ & $2009,2010,2012$ & $0.241^{*}$ & 2009,2010 & $0.138^{*}$ & $2009,2010,2012$ \\
\hline Croatia & $0.140^{*}$ & $2009,2010,2012$ & $0.159^{*}$ & $2009,2010,2011$ & $0.226^{*}$ & 2009,2011 \\
\hline Czech Republic & $0.082^{*}$ & $2009,2012,2013$ & $0.143^{*}$ & $2009,2011,2012$ & $0.191^{*}$ & 2011,2012 \\
\hline Estonia & $0.119^{*}$ & $2008,2009,2011$ & $0.227^{*}$ & 2009,2011 & $0.157^{*}$ & $2010,2011,2012$ \\
\hline Hungary & $0.126^{*}$ & $2009,2010,2012$ & $0.186^{*}$ & $2009,2010,2011$ & $0.106^{*}$ & 2010,2011 \\
\hline Latvia & $0.092^{*}$ & $2008,2009,2010$ & $0.193^{*}$ & $2009,2010,2011$ & $0.213^{*}$ & $2009,2010,2011$ \\
\hline Lithuania & $0.197^{*}$ & 2009,2010 & $0.219^{*}$ & $2009,2010,2011$ & $0.188^{*}$ & $2010,2011,2012$ \\
\hline Poland & $0.082^{*}$ & 2009,2010 & $0.125^{*}$ & 2009,2010 & $0.203^{*}$ & $2009,2010,2011$ \\
\hline Romania & $0.141^{*}$ & 2009,2010 & $0.116^{*}$ & 2009,2010 & $0.127^{*}$ & 2010,2011 \\
\hline Slovakia & $0.173^{*}$ & 2008,2009 & $0.271^{*}$ & 2009,2010 & $0.173^{*}$ & $2009,2010,2011$ \\
\hline Slovenia & $0.145^{*}$ & $2009,2010,2012$ & $0.207^{*}$ & 2010,2011 & $0.236^{*}$ & 2009,2010 \\
\hline Panel & $0.137^{*}$ & & $0.225^{*}$ & & $0.185^{*}$ &
\end{tabular}

Source: Authors' own elaboration based on the results of PANKPSS unit root test

Notes: * it is stationary at $5 \%$ significance level.

Critical values were generated with 1000 simulations.

Table 4. Results of Basher and Westerlund (2009) Cointegration Test

\begin{tabular}{lcc} 
Model & Test Statistic & $p$-value \\
\hline Exclusion of structural breaks in the constant term and trend & 1.472 & 0.016 \\
\hline Consideration of structural breaks in the constant term and trend & 32.983 & 0.194 \\
\hline
\end{tabular}

Source: Authors' own elaboration based on the results of Basher and Westerlund (2009) panel cointegration test

Table 5. Estimation of Cointegrating Coefficients

\begin{tabular}{lcc} 
Variables & Coefficient & $p$-value \\
\hline DGFDI & $0.1891^{*}$ & $0.013^{*}$ \\
\hline DBFDI & $0.1374^{*}$ & $0.005^{*}$ \\
\hline
\end{tabular}

Source: Authors' own elaboration based on the results of AMG estimation

\section{Dumitrescu and Hurlin (2012) panel causality test}

The causal relationship among greenfield investments, brownfield investments, and the economic growth was investigated with the causality test of Dumitrescu and Hurlin
(2012), which takes notice of the heterogeneity (the results are displayed in Table 6).

The null hypothesis, "there is no causality relationship" for the causality interaction between both DGFDI and DGRW

Table 6. Results of Dumitrescu and Hurlin (2012) Panel Causality Test

\begin{tabular}{lccc} 
Lags: $\mathbf{2}$ & & \\
\hline Null Hypothesis & W-Stat. & Zbar-Stat. & -value \\
\hline DGRW $\nrightarrow$ DGFDI & 2.9854 & 0.36342 & 0.1375 \\
\hline DGFDI $\nrightarrow$ DGRW & $\mathbf{6 . 4 8 5 8}$ & $\mathbf{7 . 9 5 3 5}$ & $\mathbf{0 . 0 0 6 4}$ \\
\hline DGRW $\nrightarrow$ DBFDI & 3.0531 & 0.89342 & 0.2375 \\
\hline DBFDI $\nrightarrow$ DGRW & $\mathbf{7 . 6 3 4 3}$ & $\mathbf{4 . 7 7 3 1}$ & $\mathbf{0 . 0 2 7 4}$ \\
\hline
\end{tabular}

Source: Authors' own elaboration based on the results of Dumitrescu and Hurlin (2012) panel causality test 
and DBFDI and DGRW, was rejected, because the $p$-values were found to be lower than 5\%. Thus the test results revealed a one-way causality from greenfield and brownfield investments to the economic growth. In other words, greenfield and brownfield investments had significant impact on the economic growth in the short term.

\section{Conclusion}

FDI inflows have potential to positively influence economic growth by way of making contributions to the capital accumulation or through knowledge and technological spillovers. Furthermore, FDI inflows can indirectly affect the economic growth through enhancing financial development. But FDI-growth interaction can differ depending on type of FDI inflows. On the one hand, greenfield investments can contribute to the capital accumulation and productivity with forming new facilities, while brownfield investments, including M\&As, can positively influence economic growth by means of new knowledge and technology transfer.

This study researched the influence of foreign direct investment inflows in terms of greenfield and brownfield investments on economic growth in Central and Eastern European Union countries during the 2003-2015 period, via employing the Basher and Westerlund (2009) cointegration test and Dumitrescu and Hurlin (2012) causality tests, because Central and Eastern European Union countries have attracted a significant amount of foreign direct investment flows after transition, especially as of the mid-1990s. The results of the econometric analysis revealed that both greenfield and brownfield investments made a positive contribution to economic growth, but the influence of greenfield investments was found to be relatively higher. Furthermore, the results of causality analysis revealed a one-way causality from greenfield and brownfield investments to economic growth.

Our findings support the theoretical considerations, which suggest both greenfield and brownfield investments positively influence economic growth by raising the accumulation of capital, productivity, and transfer of knowledge and technology. However, future studies can be conducted to see that through which channels greenfield and brownfield investments affect economic growth. Finally, policymakers should consider the positive effects of greenfield and brownfield investments on economic growth and take economic and institutional measures to attract especially greenfield investments.

\section{Acknowledgments}

This study was presented at the International Conference on "Economic policy for smart, sustainable and inclusive growth,” Belgrade University, Republic of Serbia, 15-17 June 2017.

\section{References}

Ashraf, A., Herzer, D., \& Nunnenkamp, P. (2015). The effects of greenfield FDI and cross-border M\&As on total factor productivity. World Economy, 39(11), 1728-1755. https://doi.org/10.1111/twec.12321

Basher, S. A., \& Westerlund, J. (2009). Panel cointegration and the monetary exchange rate model. Economic Modelling, 26(2), 506-513. https://doi.org/10.1016/j.econmod.2008.10.006

Borensztein, E., De Gregorio, J., \& Lee, J.W. (1998). How does foreign direct investment affect economic growth? Journal of International Economics, 45, 115-135. https://doi.org/10.1016/S0022-1996(97)00033-0

Breusch, T. S., \& Pagan, A. R. (1980). The Lagrange multiplier test and its applications to model specification in econometrics. Review of Economic Studies, 47(1), 239-253. http://dx.doi.org/10.2307/2297111

Calderón, C., Loayza, N., \& Servén, L. (2004). Greenfield foreign direct investment and mergers and acquisitions: Feedback and macroeconomic effects. World Bank Policy Research Working Paper 3192. https://doi.org/10.1596/1813-9450-3192

Carrion-i-Silvestre, J. L., del Barrio, T., \& López-Bazo, E. (2005). Breaking the panels: An application to the GDP per capita. Econometrics Journal, 8(2), 159-175. https://doi.org/10.1111/j.1368-423X.2005.00158.x

De Mello, L. R. (1999). Foreign direct investment-led growth: evidence from time series and panel data. Oxford Economic Papers, 51(1), 133-151. https://doi.org/10.1093/oep/51.1.133

Dumitrescu, E. I., \& Hurlin, C. (2012). Testing for Granger non-causality in heterogeneous panels. Economic Modelling, 29(4), $1450-1460$. http://dx.doi.org/10.1016/j.econmod.2012.02.014

Eberhardt, M., \& Bond, S. (2009). Cross-section dependence in nonstationary panel models: A novel estimator. Retrieved from https://mpra.ub.uni-muenchen.de/17870/ (03.04.2017)

Eren, M., \& Zhuang, H. (2015). Mergers and acquisitions versus greenfield investment, absorptive capacity, and economic growth: Evidence from 12 new member states of the European Union. Eastern European Economics, 53(2), 99-123. http://dx.doi.org/10.108 0/00128775.2015.1033240 
Harms, P., \& Meon, P-G. (2014). Good and bad FDI: The growth effects of greenfield investment and mergers and acquisitions in developing countries. CEB Working Paper N 14/021. Retrieved from https://dipot.ulb.ac.be/dspace/bitstream/2013/174783/1/wp14021.pdf (05.01.2017)

lamsiraroj, S. (2016). The foreign direct investment-economic growth nexus. International Review of Economics and Finance, 42, $116-133$. https://doi.org/10.1016/j.iref.2015.10.044

lamsiraroj, S., \& Ulubaşoğlu, M. A. (2015). Foreign direct investment and economic growth: A real relationship or wishful thinking? Economic Modelling, 51, 200-213. https://doi.org/10.1016/j.econmod.2015.08.009

Luu, H. N. (2016). Greenfield investments, cross-border M\&As, and economic growth in emerging countries. Economics and Business Letters, 5(3), 87-94. https://doi.org/10.17811/ebl.5.3.2016.87-94

Li, X., \& Liu, X. (2005). Foreign direct investment and economic growth: An increasingly endogenous relationship. World Development, 33(3), 393-407. https://doi.org/10.1016/j.worlddev.2004.11.001

Moon, H.-C., Kim, H.-K., \& Lee, D.-H. (2003). Cross-border mergers \& acquisitions: Case studies of Korea; China; and Hong Kong, China. Asia-Pacific Economic Cooperation Research Paper, 203-CT-01.6.

Neto, P., Brandão, A., \& Cerqueira, A. (2010). The impact of FDI, cross border mergers and acquisitions and greenfield investments on economic growth. IUP Journal of Business Strategy, 7(4), 24-45.

Pegkas, P. (2015). The impact of FDI on economic growth in Eurozone countries. Journal of Economic Asymmetries, 12, 124-132. https:// doi.org/10.1016/j.jeca.2015.05.001

Pesaran, M. H., Ullah, A., \& Yamagata, T. (2008). A bias-adjusted LM test of error cross-section independence. Econometrics Journal, 11(1), 105-127. http://dx.doi.org/10.1111/j.1368-423X.2007.00227.x

Pesaran, M. H., \& Yamagata, T. (2008). Testing slope homogeneity in large panels. Journal of Econometrics, 142(1), 50-93. http://dx.doi. org/10.1016/j.jeconom.2007.05.010

Solow, R. M. (1957). Technical change and the aggregate production function. Review of Economics and Statistics, 39(3), 312-320. https:// doi.org/10.2307/1926047

UNCTAD (2016). World Investment Report 2016: Annex Tables. Retrieved from http://unctad.org/en/Pages/DIAE/World\%20 Investment\%20Report/Annex-Tables.aspx (21.10.2016) https://doi.org/10.18356/9d7da2eb-en

Wang, M., \& Wong, M.C.S. (2009). What drives economic growth? The case of cross border M\&A and greenfield FDI activities. Kyklos, 62(2), 316-330. https://doi.org/10.1111/j.1467-6435.2009.00438.x

World Bank (2016). GDP per capita growth (annual \%). Retrieved from http://data.worldbank.org/indicator/NY.GDP.PCAP.KD.ZG (21.10.2016)

World Bank (2017). Foreign direct investment, net inflows (BoP, current US\$). Retrieved from http://data.worldbank.org/indicator/ BX.KLT.DINV.CD.WD (10.04.2017)

Zhuang, H., \& Griffith, D. (2013). The effect of mergers \& acquisitions and greenfield FDI on income inequality. International Journal of Applied Economics, 10(1), 29-38.

Zvezdanović-Lobanova, L., Kračun, D., \& Kavkler, A. (2016). Growth effects of cross-border mergers and acquisitions in European transition countries. Naše gospodarstvo/Our Economy, 62(4), 3-11. https://doi.org/10.1515/ngoe-2016-0019

\section{Author}

Yılmaz Bayar was born in Malatya, Turkey, in 1977. He completed navy high school in 1995, graduated from the Naval Academy in 1999, and served 13 years in the navy. He was awarded the master degrees in the field of accounting and finance from Marmara University Institute of Social Sciences in 2006, in the field of international economics and finance from Bahcesehir University Institute of Social Sciences in 2007, and in the field of international relations and globalization from Kadir Has University Institute of Social Sciences in 2008. He was also awarded a PhD degree in the field of economics in Istanbul University Institute of Social Sciences in 2012. He worked as an assistant professor in the Faculty of Business, Karabuk University, during the period from September 2012-March 2015 and now working as an associate professor in the Faculty of Economics and Administrative Sciences, Usak University, since March 2015. 


\section{Greenfield in brownfield tuje neposredne naložbe in gospodarska rast: izsledki iz srednje- in vzhodnoevropskih držav članic Evropske unije}

\section{Izvleček}

Tokovi globalnih greenfield in brownfield tujih neposrednih naložb so se $v$ zadnjih treh desetletjih zaradi pospešene globalizacije povečali.Znatna povečanja tokov tujih neposrednih naložb imajo veliko možnih vplivov na narodna gospodarstva. V študiji z uporabo analize panelnih podatkov raziskujemo medsebojne učinke greenfield in brownfield (spojitev in pripojitev) naložb in gospodarske rasti v srednje- in vzhodnoevropskih državah članicah Evropske unije v obdobju 2003-2015. Izsledki kažejo, da imajo tako greenfield kot tudi brownfield tuje neposredne naložbe pozitiven vpliv na gospodarsko rast, pri čemer je vpliv greenfield naložb relativno večji. Nadalje, ugotovljen je bil enosmerni vpliv tako greenfield kot tudi brownfield naložb na gospodarsko rast.

Ključne besede: greenfield tuje neposredne naložbe, brownfield naložbe, gospodarska rast, analiza panelnih podatkov, srednje- in vzhodnoevropske države članice Evropske unije 